\title{
The Effect of the pH of Ammonum Nitrate Solution on the Susceptability of Mild Steel to Stress Corrosion Cracking (SCC) and General Corrosion
}

\author{
Fathia S. Mohammed ${ }^{1}$, Alyaa G. Elramady², Salheddin E. Abu Yahya ${ }^{2}$ \\ ${ }^{1}$ Department of Chemical Engineering, American University of Sharjah, Sharjah, United Arab Emirates; ${ }^{2}$ The Petroleum Institute, \\ Abu Dhabi, United Arab Emirates. \\ Email: fmohammed@aus.edu
}

Received April 18 ${ }^{\text {th }}, 2010$; revised August $6^{\text {th }}, 2010$; accepted August $16^{\text {th }}, 2010$.

\begin{abstract}
This work investigates the relative aggressiveness of nitrate solutions at different $\mathrm{pH}$ values on mild steel towards stress corrosion cracking (SCC) and general corrosion. Electrochemical behavior and stress corrosion cracking susceptibility measurements were carried out in $52 \mathrm{Wt} \%$ ammonium nitrate solutions at $368^{\circ} \mathrm{K}$ and various $\mathrm{pH}$ values ranging from 0.77 to 9.64. Constant load stress corrosion test at $90 \%$ yield stress was conducted. Tested specimens were prepared and examined using the scanning electron microscope (SEM). The potentiodynamic polarization curves for different $p H$ values again emphasized the validity of the gravimetric measurements and hence the mechanism of cracking was attributed to the stress that assisted the dissolution process.
\end{abstract}

Keywords: Stress Corrosion Cracking, Ammonium Nitrate Solution, Mild Steel, Constant Load Test, Effect of PH

\section{Introduction}

Stress corrosion cracking (SCC) can lead to rapid and catastrophic failure in many different metals and alloys. This phenomenon occurs under conditions where a component is exposed to a mildly corrosive environment while under applied and/or residual tensile stress. Hence, metal parts with severe SCC can appear bright and shiny whilst being filled with microscopic cracks [1]. These factors along with the rapid progress of SCC make it common for SCC to go undetected prior to failure. Steel/ nitrate interaction is an issue in nitrogenous fertilizer plants, waste heat recovery boilers (WHRBs) in power generating plant and nuclear wastes [2].

The effect of $\mathrm{pH}$ and types of nitrate solution has been investigated [3], which concluded that the order of decreasing aggressiveness of nitrate solutions corresponded to the order of increasing (initial) $\mathrm{pH}$ for a given chemical strength, i.e., $\mathrm{NH}_{4}{ }^{+}, \mathrm{Ca}^{++}, \mathrm{K}^{+}, \mathrm{Na}^{+}$.

The aggressiveness of ammonium nitrate when compared to other nitrates was attributed to its lower $\mathrm{pH}$. Parkins [4] reported that the marked decrease in potency at initial $\mathrm{pH}$ values in the region number 4 compared to either slightly higher or lower values depends probably upon $\mathrm{pH}$ changes in the solution during the test. The above work was concerned with the changes in $\mathrm{pH}$ of the bulk of solution and not with the $\mathrm{pH}$ at the crack tip region, which undoubtedly more acidic. Steel has been characterized as being very susceptible to SCC at nearneutral pH [5].

In this work a comprehensive study on the effect of the $\mathrm{pH}$ of ammonium nitrate solution on the susceptibility of mild steel to stress corrosion cracking and general corrosion was carried out. The results indicate that in some $\mathrm{pH}$ values the general and localized corrosion were the cause of failure. In other $\mathrm{pH}$ values the stress corrosion cracking were the cause of failures. The severity was confirmed by the calculation of crack growth rate, morphology of the fracture surface by SEM and by polarization work.

\section{Experimental Approach}

\subsection{Material}

The work was carried out on mild steel of the following 
composition (wt\%):

C 0.070, Mn 0.300, Si 0.093, S 0.044, P 0.019. The Material was supplied in the form of $19 \mathrm{~mm}$ diameter rods. The corroding solution was prepared by using ammonium nitrate.

\subsection{Specimen Preparation}

\subsubsection{Electrochemical Measurement}

The steel rods were hot-rolled at $1200^{\circ} \mathrm{K}$ to $4 \mathrm{~mm}$ thick strips. This was reheated to $1200^{\circ} \mathrm{K}$ in the furnace for $900 \mathrm{~s}$, and then allowed to cool to room temperature. Most of the oxide film was removed by pickling in 30\% $\mathrm{HCl}$ solution, and the surface was finally cleaned for coldrolling by mechanical abrasion. The strips were reduced to $0.5 \mathrm{~mm}$ thick by cold-rolling.

Samples of $20 \mathrm{~mm}$ by $13 \mathrm{~mm}$ were prepared. A $3 \mathrm{~mm}$ holes were drilled at one end to suspend the samples, then the specimens were degreased with ether, annealed at $1200^{\circ} \mathrm{K}$ for $3.6 \mathrm{ks}$. The specimens were attached to the holder and the whole assembly coated apart from an area of $100 \mathrm{~mm}^{2}$ on one face.

\subsubsection{Stress Corrosion Measurement}

The steel rod was hot-rolled at $1200^{\circ} \mathrm{k}$ and swaged cold to approximately $10 \mathrm{~mm}$ diameter. It was then annealed at $1200^{\circ} \mathrm{k}$ for $900 \mathrm{~s}$, furnace cooled to $850^{\circ} \mathrm{k}$, followed by air cooling to room temperature. The specimens were machined from the rod as shown in Figure 1. They have a gauge length of $15.8 \mathrm{~mm}$ and a gauge diameter of 3.2 $\mathrm{mm}$.

\subsubsection{General Corrosion Testing}

Samples of $40 \mathrm{~mm}$ by $15 \mathrm{~mm}$ were prepared. A $3 \mathrm{~mm}$ holes were drilled at one end to suspend the samples, then the specimen were degreased with ether, annealed at $1200 \mathrm{k}$ for $3.6 \mathrm{ks}$.

\subsection{Apparatus}

\subsubsection{Electrochemical Measurements}

For electrochemical measurements on unstressed specimens, a glass cell comprising two compartments was designed. The main compartment contained the working electrode and the platinum counter electrode. The reference compartment contained a saturated calomel electrode. The complete cell is shown in Figure 2. The two compartments were connected by a salt bridge with a Luggin capillary. The glass joints that carried the working and the counter electrodes also had a screw cap joint for the thermometer. There was another two openings in the main compartment, one for water condenser, and the other for gas and solution inlet, when working with de-aerated system. The reference compartment has a thermometer gas inlet and liquid inlet together with the

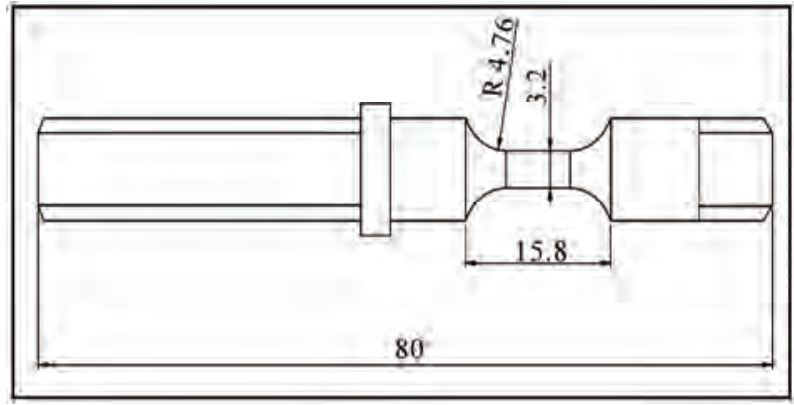

Figure 1. Stress corrosion test specimen (dimensions in mm).

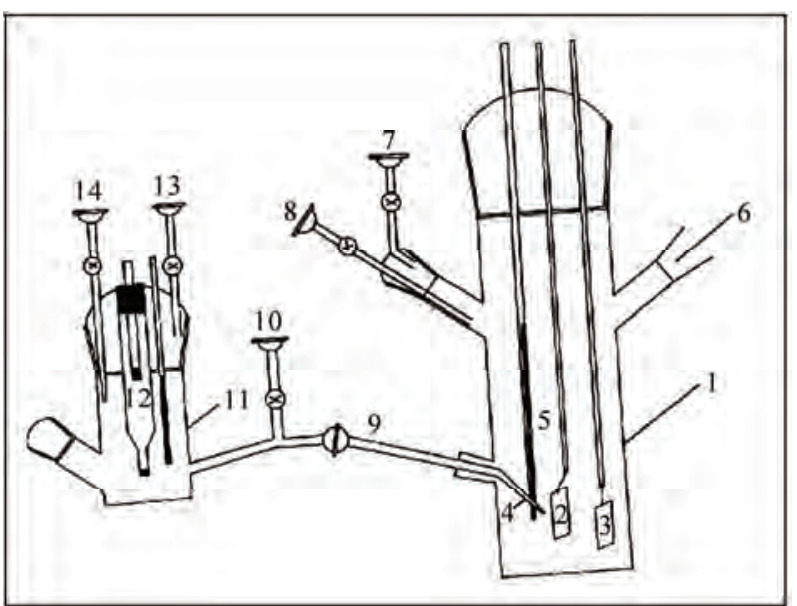

Figure 2. Electrochemical polarization cell (schematic). 1) Main compartment; 2) Specimen/working electrode; 3) Platinum electrode; 4) Luggin capillary; 5) Thermometer; 6) Condenser and gas outlet; 7) \& 13) Solution inlet; 8) \& 14) Gas inlet; 9) Salt bridge; 10) Gas Outlet; 11) Reference compartment; 12) Saturated calomel reference electrode.

saturated calomel electrode in one joint. The cell capacity is $0.4 \mathrm{dm}^{3}$ of test solution. Only the main compartment of the cell was immersed in an oil bath controlling the required temperature, the reference compartment was held at room temperature.

\subsubsection{Stress Corrosion Measurement}

The majority of the work was conducted using the constant load method. The tensile properties of the material were measured in triplicate using Instron Tensile Testing Machine. In all the constant load tests the load applied was $90 \%$ of the predetermined yield stress.

For electrochemical measurements on stressed specimens, a glass cell consisting of two compartments was used; the main compartment contained the stress corrosion specimen and the platinum counter electrode. The reference compartment contained the saturated calomel electrode, similar to the reference compartment described before. The two compartments were connected by a salt 
bridge with a Luggin capillary. The capacity of the cell is $0.25 \mathrm{dm}^{3}$, and the details are shown in Figure 3.

\subsubsection{General Corrosion Measurement}

A flat-bottomed one-liter glass vessel with two necks was used. One neck held the water condenser; the specimens were suspended by a glass hook from the lower end of the condenser. A thermometer, inserted through the second neck.

\section{Results and Discussion}

To validate the results, all measurements were conducted at least three times under each specific environment.

\subsection{Stress Corrosion Life and Corrosion Potential}

The entire stress corrosion test carried out under a constant load of $90 \%$ of the yield stress $\left(206.5 \mathrm{MN} \mathrm{m}^{-2}\right)$. A series of stress corrosion tests were carried out to determine the stress corrosion life in $52 \mathrm{Wt} \% \mathrm{NH}_{4} \mathrm{NO}_{3}$ solution at $368^{\circ} \mathrm{k}$ and various $\mathrm{pH}$ values ranging from 0.77 to 9.64. The corrosion potential was also recorded during the tests.

Figures 4, 5 and 6 show the changes in the corrosion potential during the stress corrosion test at different $\mathrm{pH}$ values. In solution of $\mathrm{pH} 2.78$ and above jumps in the corrosion potential to more negative values were observed before failure occurs. At $\mathrm{pH} 0.77$, no oscillations were observed.

Figure 7 shows the whole range of potential change, the initial and the final $\mathrm{pH}$ of the solution, and the stress corrosion life for some of the above tests. For lower $\mathrm{pH}$ values, the $\mathrm{pH}$ was more basic at the end of the test, while at high $\mathrm{pH}$ values (5.7 and above), the $\mathrm{pH}$ became more acidic at the end of the test. While results indicate that the critical range for cracking (i.e., where the stress corrosion life is minimum) is between $\mathrm{pH} 3.0$ and $\mathrm{pH}$ 7.5, cracking occurs even at $\mathrm{pH} 9.6$ but after very long period of time.

Staehle [6] reported that with respect to $\mathrm{pH}$, a change of one unit of $\mathrm{pH}$ changes the solubility of oxide by three orders of magnitude for three valent ions such as $\mathrm{Fe}^{3+}$ and by two orders of magnitude for two valent ion such as $\mathrm{Fe}^{2+}$. It was reported that nuclear waste are all alkaline, with $\mathrm{pH}$ in the range 11-14. Even under these highly alkaline conditions, the presence of certain constituents, such as nitrates can make the carbon steel susceptible to SCC [7]. Other researchers indicated that elevated $\mathrm{pH}$ are long considered corrosion inhibitors and did not have a dominant effect on the susceptibility to SCC in the range 10$13.5[8,9]$.

Figure 8 summarizes the relation between the $\mathrm{pH}$ of

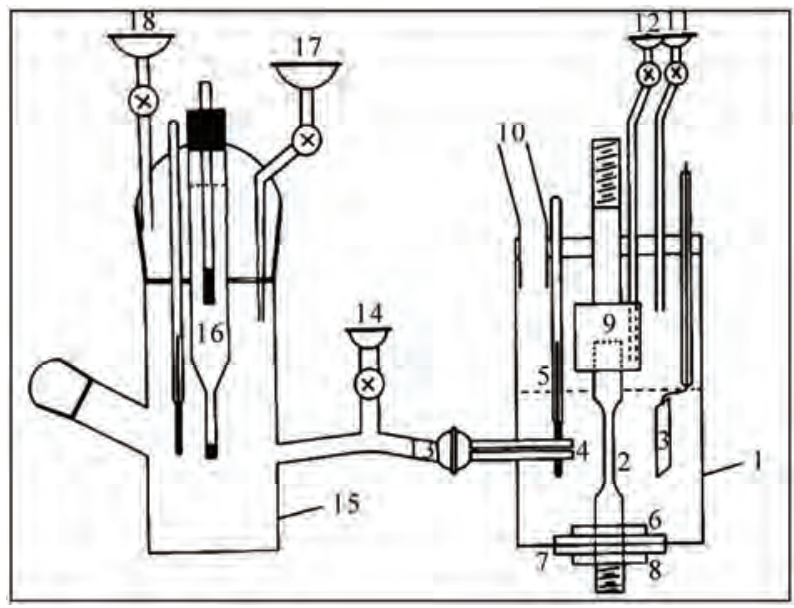

Figure 3. Stress corrosion test cell (schematic). 1) Main compartment; 2) Specimen/working electrode; 3) Platinum electrode; 4) Luggin capillary; 5) Thermometer; 6) P.T.F.E nut; 7) Rubber washers; 8) Stainless steel nut; 9) Top shackle; 10) To condenser and gas outlet; 11, 18) Solution inlets; 12, 17) Gas inlets; 13) Salt bridge outlet; 14) Gas outlet; 15) Reference compartment; 16) Saturated calomel reference electrode.

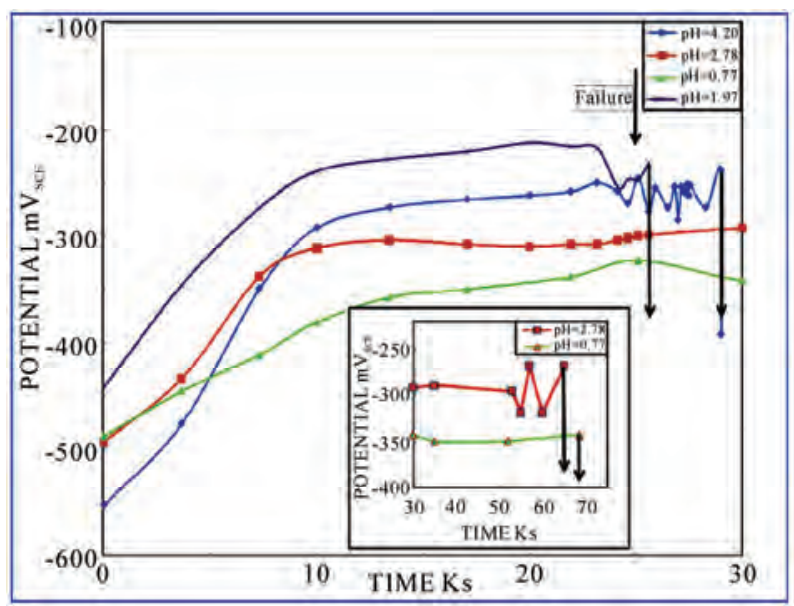

Figure 4. Effect of pH on the corrosion potential/time behavior of mild steel during stress corrosion testing in $52 \mathrm{Wt} \%$ $\mathrm{NH}_{4} \mathrm{NO}_{3}$ at $368^{\circ} \mathrm{K}$.

the solution and the corrosion potential at different time during the test. The graph shows no straight forward systematic correlation between the $\mathrm{pH}$ of the solution and the potential.

\subsection{Metallographic Examination}

Selected specimens were prepared for examination using the scanning electron microscope and the ordinary metallographic microscope. The results are in Table 1.

Figures 9(a) and 9(b) show a fracture surface of a specimen which was stress corroded in a solution of $\mathrm{pH}$ 


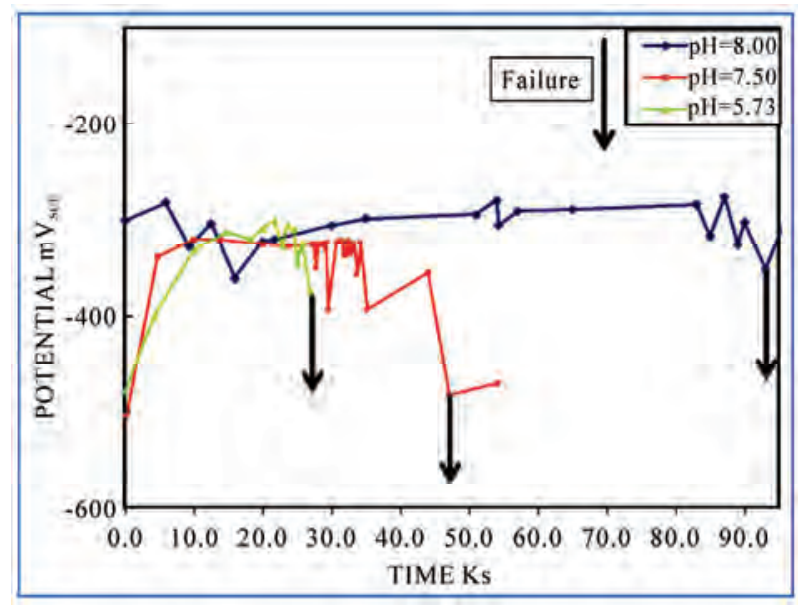

Figure 5. Effect of $\mathbf{p H}$ on the corrosion potential/time behavior of mild steel during stress corrosion testing in $52 \mathrm{Wt} \%$ $\mathrm{NH}_{4} \mathrm{NO}_{3}$ solutions at $368^{\circ} \mathrm{K}$.

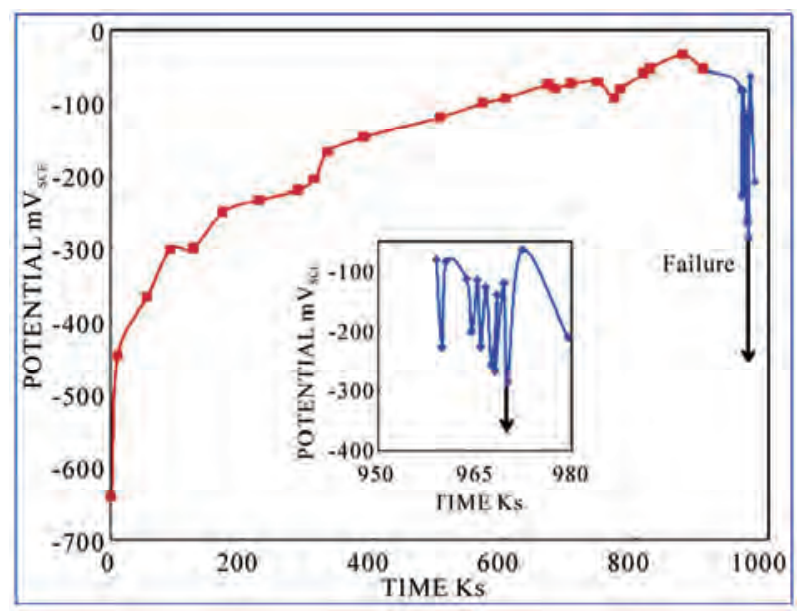

Figure 6. Effect of $\mathrm{pH}$ on the corrosion potential/time behavior of mild steel during stress corrosion testing in $52 \mathrm{Wt} \%$ $\mathrm{NH}_{4} \mathrm{NO}_{3}$ at $368^{\circ} \mathrm{K}$. (pH 9.64).

0.77. The first shows an area where localized attack has occurred, whilst the second shows the ordinary structure.

The crack growth rate was very small $\left(3 \mathrm{nms}^{-1}\right)$ with big reduction of the specimen diameter $(660 \mu \mathrm{m})$ which indicates the high general and intergranular corrosion occurs during the test.

Very heavy attack was observed when specimens were broken in a solution of $\mathrm{pH} 4.2$.

Figure 10 Illustrates part of the fracture surface. It is clear that that cracking occurs and the cracking rate was very high (71 $\left.\mathrm{nms}^{-1}\right)$, with very small reduction in the diameter $(8 \mu \mathrm{m})$ which indicates the severity of such environment.

Figure 11 shows a specimen which was stress corroded in a solution of $\mathrm{pH} 9.64$.

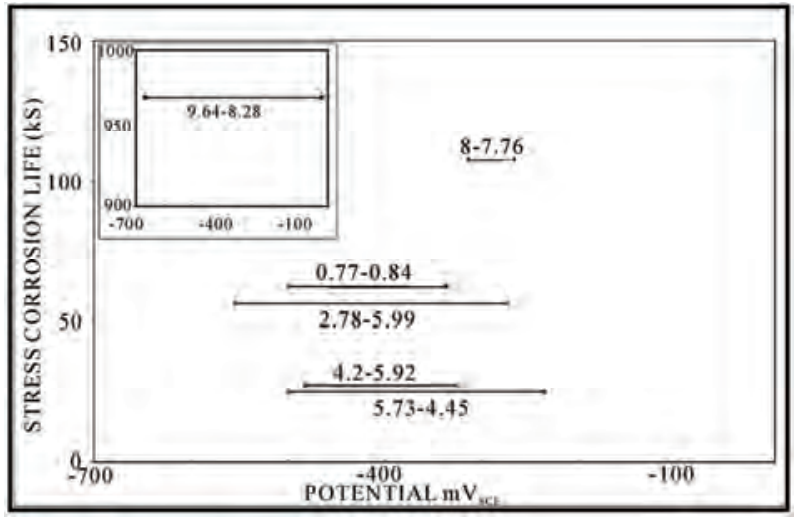

Figure 7. The relationship between stress corrosion life, corrosion potential variations and solution $\mathrm{pH}$ changes for mild steel in $52 \mathrm{Wt} \% \mathrm{NH}_{4} \mathrm{NO}_{3}$ solutions at $368^{\circ} \mathrm{K}$.

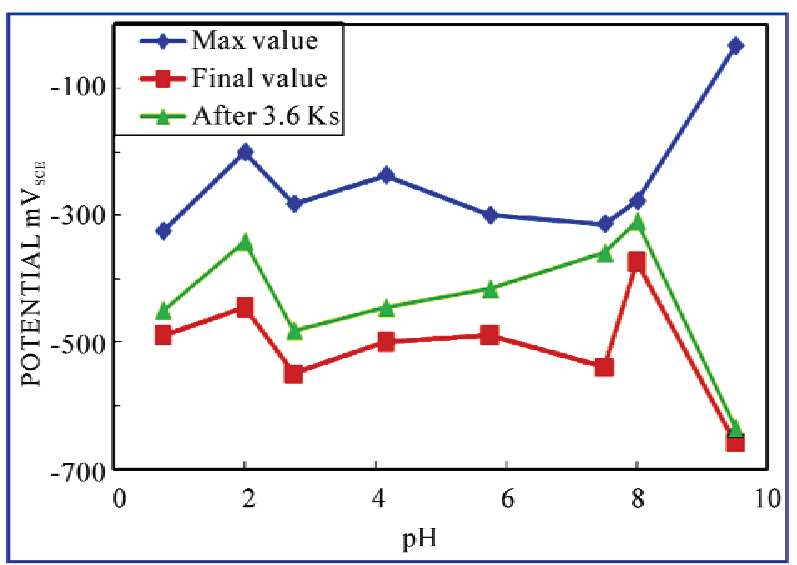

Figure 8. Effect of $\mathrm{pH}$ on the corrosion potential of mild steel under applied stress in $52 \mathrm{Wt} \% \mathrm{NH}_{4} \mathrm{NO}_{3}$ solutions at $368^{\circ} \mathrm{K}$.

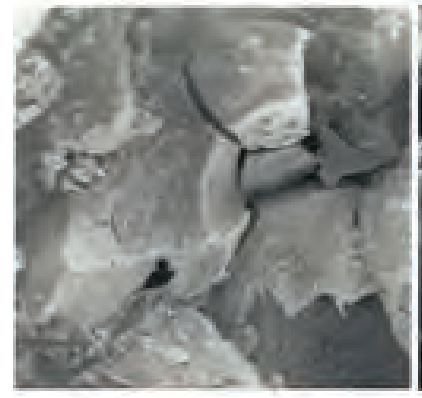

(a)

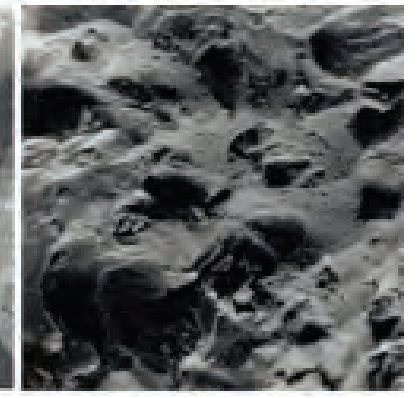

(b)
Figure 9. Fracture surface morphologies of a stress corrosion specimen after failure in $\mathrm{NH}_{4} \mathrm{NO}_{3}$ solution of $\mathrm{pH} 0.77$ at $368^{\circ} \mathrm{K}$ ( $\left.\mathrm{X} 950\right)$. (a) localized intergranular attack and cracking; (b) Ductile failure.

In summary the results of the present work indicate the following facts: 1) a presence of stress corrosion cracking at high $\mathrm{pH}$ values (pH 9.64, Figures 6, 11 and Table 1). 2) 
The Effect of the pH of Ammonum Nitrate Solution on the Susceptability of Mild Steel to

Stress Corrosion Cracking (SCC) and General Corrosion

Table 1. The Effect of pH on the stress corrosion life and morphology of attack in $52 \mathrm{Wt} \% \mathrm{NH}_{4} \mathrm{NO}_{3}$ solution at $368^{\circ} \mathrm{K}$.

\begin{tabular}{|c|c|c|c|c|c|c|c|}
\hline \multirow{2}{*}{$\mathrm{pH}$} & \multirow{2}{*}{$\begin{array}{l}\text { Average Stress } \\
\text { Corrosion Life } \\
\text { (Ks) }\end{array}$} & \multicolumn{3}{|c|}{$\begin{array}{c}\text { Type of Attack and Number } \\
\text { of Locations }\end{array}$} & \multirow{2}{*}{$\begin{array}{l}\text { Maximum Depth of } \\
\text { Penetration in } \\
\text { Grains }\end{array}$} & \multirow{2}{*}{$\begin{array}{l}\text { Reduction in } \\
\text { Diameter }(\mu \mathrm{m})\end{array}$} & \multirow{2}{*}{$\begin{array}{l}\text { Crack Growth } \\
\text { Rate (nm/sec) }\end{array}$} \\
\hline & & A & B & C & & & \\
\hline 0.77 & 62.64 & 3 & & & 5 & 660 & 3.2 \\
\hline 2.78 & 56.5 & & 7 & & 25 & - & 17.7 \\
\hline 4.2 & 27.3 & & 6 & 1 & 44 & 8 & 71 \\
\hline 8.8 & 108 & & 1 & & 7 & - & 2.6 \\
\hline 9.64 & 970.2 & & & 2 & - & - & - \\
\hline
\end{tabular}

A: Fine cracks; B: Wide cracks; C: Cracks visible to the naked eye

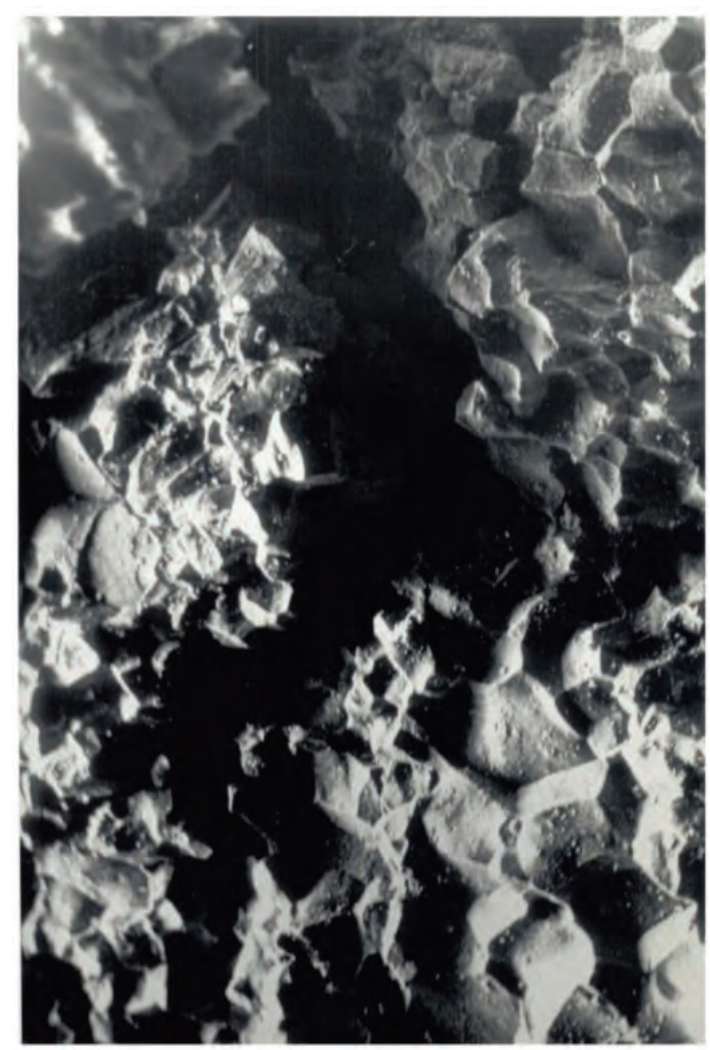

Figure 10. Fracture surface morphology of a specimen after stress corrosion failure in $52 \mathrm{Wt} \% \mathrm{NH}_{4} \mathrm{NO}_{3}$ solution of $\mathrm{pH}$ 4.2 at $368^{\circ} \mathrm{K}$ showing the high degree of intergranular attack (X 250).

The high potency of the solution at $\mathrm{pH} 2.78$ compared to lower or higher $\mathrm{pH}$ values (Figure 4). 3) In a solution of $\mathrm{pH}$ 0.77, the SCC was associated with high rate of general attack (Figure 4, Figure 9 and Table 1).

Naris Sridhar et al. [10] reported that intergranular stress corrosion cracking (IG SCC) has generally not been observed when the $\mathrm{pH}$ greater than 11.0. According to potential $\mathrm{pH}$ or pourbaix diagram [11] dangerous zones

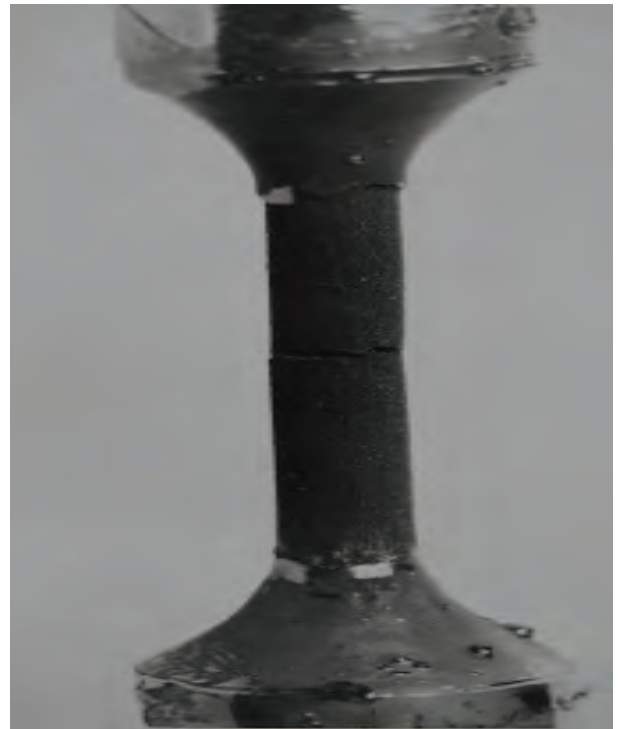

Figure 11. An illustration of catastrophic crack formation in a stress corrosion specimen after failure in $52 \mathrm{Wt} \%$ $\mathrm{NH}_{4} \mathrm{NO}_{3}$ solutions of $\mathrm{pH} 9.64$ at $368^{\circ} \mathrm{K}$.

where SCC caused by nitrate solution is between $\mathrm{pH} 2.2$ and 5.2, with corresponding potential between 0 -I000 $\mathrm{mV}_{\mathrm{SCE}}$.

Parkins et al. [12] reported that changes in the $\mathrm{pH}$ during the test show more relation to the results than the initial $\mathrm{pH}$ values. They showed that the time to failure correlated more significantly with the final $\mathrm{pH}$ of the solution than with initial values.

Relating the results shown in Figures 4, 5 and 6 to the stages of SCC indicate the followings:

- There are no sudden jumps to more active potentials before failure at a very low $\mathrm{pH}$ value $(0.77)$, and hence no indications of fast propagation period [13]. This suggests that at this $\mathrm{pH}$ value, general corrosion and not stress corrosion is the predominant factor. 
- In the $\mathrm{pH}$ range $2.0-8.0$, oscillations in potential are evident, occurring over a period representing 20 $-25 \%$ of the total life. This suggests that variations in $\mathrm{pH}$ above and below the natural $\mathrm{pH}$ of 4.2 do not affect the percentage of the total time taken up by the fast propagation period [13].

- At relatively high pH (9.64), the duration of the fast propagation period is relatively unchanged, but it occupies only about $1 \%$ of the total life. This can be attributed to the very low rate of attack at such high $\mathrm{pH}$ value.

\subsection{Corrosion Rate and Corrosion Potential Measurement on Unstressed Specimens}

Figure 12 shows the effect of $\mathrm{pH}$ of the solution on both the general corrosion rate and the stress corrosion life. This figure indicates that the increase in the stress corrosion life at lower $\mathrm{pH}$ values was associated with high general corrosion, while at higher $\mathrm{pH}$ values (greater than 7.5) it was associated with low general corrosion.

The variation of the corrosion potential with time for unstressed specimens was measured for period of $\sim 70 \mathrm{ks}$ at different pH values, ranging from 1.05 to 9.13 (Figure 13 and 14). The potential changed to the more noble direction as the test proceeded over almost the whole range of the investigated $\mathrm{pH}$ except at $\mathrm{pH} 9.13$. At this $\mathrm{pH}$ the potential at the beginning was less noble, and after approximately $30 \mathrm{ks}$ more noble values were observed.

From Figures 12, 13 and 14, the following are observed:

- High general corrosion at lower $\mathrm{pH}$ values is accompanied by a more active potential.

- The non dependence of $\mathrm{pH}$ on the corrosion rate between $\mathrm{pH}$ values of 4.2 and 6.9 is associated with unchanged corrosion potential.

- The decrease in the corrosion rate with increasing $\mathrm{pH}$ in the range $6.0-8.5$ is characterized by erratic changes in the corrosion potential, e.g. it is comparatively noble at $\mathrm{pH} 7$ and yet more active at higher values.

The above behavior probably reflected the difference of the solubility of the corrosion product in solutions of different $\mathrm{pH}$ values.

Figure 15 shows the effect of stress on the maximum corrosion potential during testing in $52 \mathrm{Wt} \% \mathrm{NH}_{4} \mathrm{NO}_{3}$ at $368^{\circ} \mathrm{K}$ at different $\mathrm{pH}$ values. The stress appears to cause a shift in the corrosion potential to more active values in the range of the critical $\mathrm{pH}$.

\subsection{Crack Growth Rate}

From the microscopic examination and the results of stress corrosion life in different $\mathrm{pH}$ values reported in Table 1, the crack growth rate was calculated by dividing

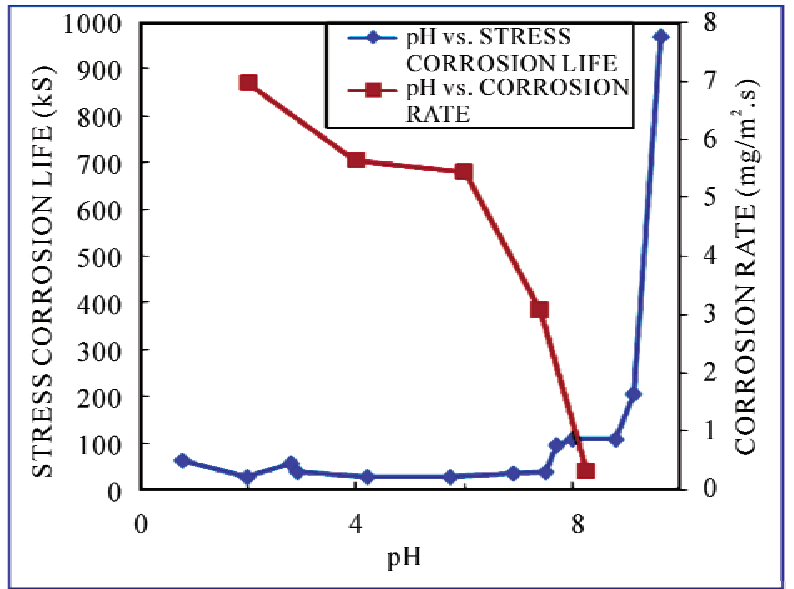

Figure 12. Effect of $\mathrm{pH}$ on the corrosion rate and stress corrosion life of mild steel in $52 \mathrm{Wt} \% \mathrm{NH}_{4} \mathrm{NO}_{3}$ solutions at $368^{\circ} \mathrm{K}$.

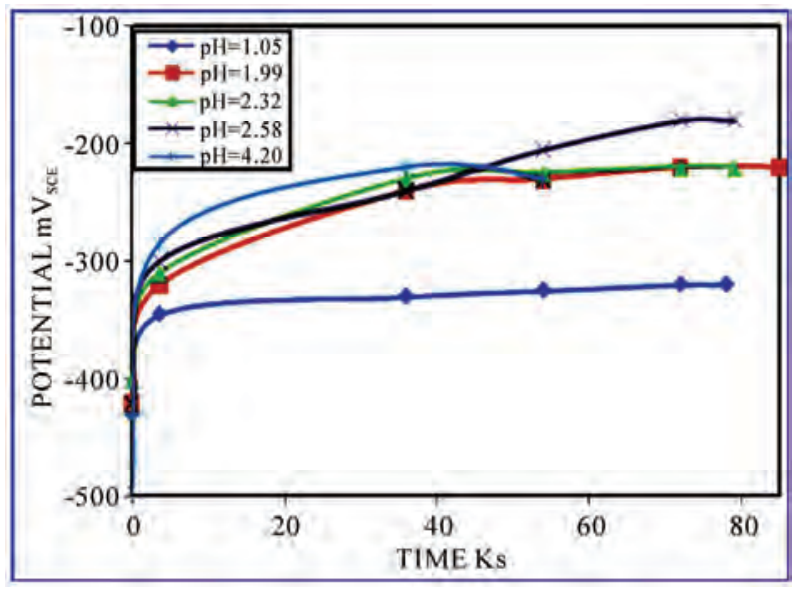

Figure 13. Effect of $\mathrm{pH}$ on the corrosion potential/time behavior of mild steel in $52 \mathrm{Wt} \% \mathrm{NH}_{4} \mathrm{NO}_{3}$ solutions at $368^{\circ} \mathrm{K}$.

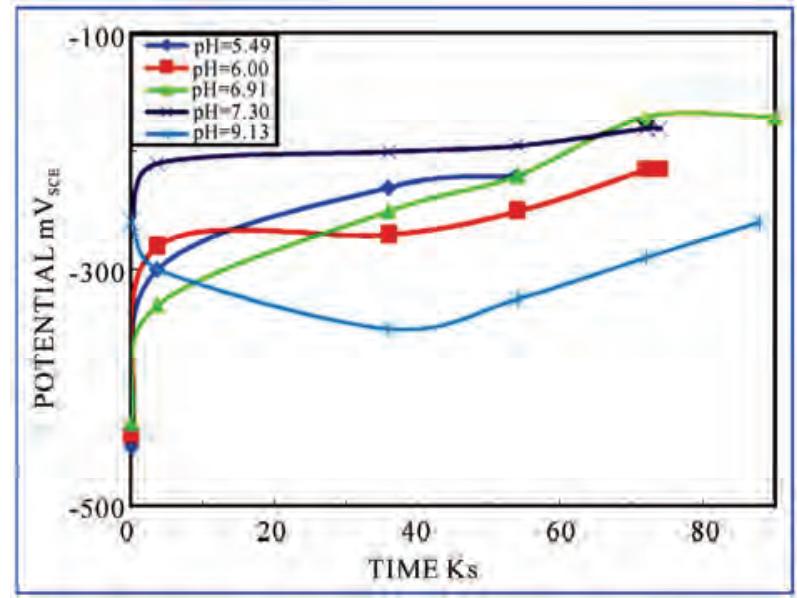

Figure 14. Effect of $\mathbf{p H}$ on the corrosion potential/time behavior of mild steel in $52 \mathrm{Wt} \% \mathrm{NH}_{4} \mathrm{NO}_{3}$ solutions at $368^{\circ} \mathrm{K}$. 


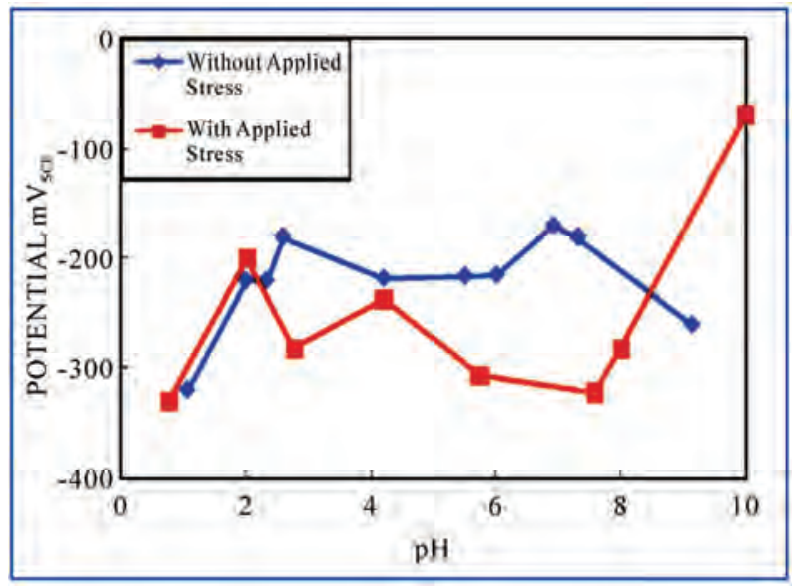

Figure 15. Effect of $\mathrm{pH}$ on the maximum corrosion potential value attained for mild steel in $52 \mathrm{Wt} \% \mathrm{NH}_{4} \mathrm{NO}_{3}$ solutions at $368^{\circ} \mathrm{K}$.

the maximum measured crack depth by the total time to failure. The obtained value gives an estimate of the rate since it does not take into account the time to initiate cracks. The growth rate of any observed cracking is assumed to be constant throughout the exposure period. These estimates provide a simple semi quantitative diagnostic to classify the SCC propensity. The following points regarding the crack growth rate are concluded from Table 1.

- In the solution of pH 0.77 the crack growth was only $3.2 \mathrm{nms}^{-1}$ but there was a big reduction (18\%) in the diameter which clearly indicates that general corrosion was dominating.

- The crack growth rate at pH 2.78 is $17.7 \mathrm{nms}^{-1}$ while

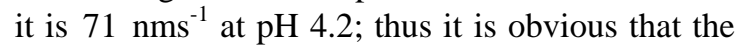
latter environment is more prone to SCC.

- In the solution of pH 8.8 the crack growth rate was $2.6 \mathrm{nms}^{-1}$ and this is probably because of the longer initiation period.

\subsection{Potentiodynamic Polarization}

Figure 16 shows the potentiodynamic polarization curves for different $\mathrm{pH}$ values of $52 \mathrm{Wt} \% \mathrm{NH}_{4} \mathrm{NO}_{3}$ solution at $368 \mathrm{~K}$ ranging from 2.04 to 8.35 .

The scanning started approximately $200 \mathrm{mv}$ more negative than the open circuit potential (OPC) in the noble direction to more than $+1500 \mathrm{mv}$ using sweep rate of 0.33 $\mathrm{mVs}^{-1}$.

Several distinct characteristics for solution of different $\mathrm{pH}$ are as below:

- For pH 2.04 1) An active dissolution regime between $-500 \mathrm{mV}_{\mathrm{SCE}}$ and $-150 \mathrm{mV}_{\mathrm{SCE}}$, 2) First passive plateau at a current density of $2 \times 10^{3} \mathrm{Am}^{-2}$ between potential $-150 \mathrm{mV}_{\mathrm{SCE}}$ and zero $\mathrm{mV}_{\mathrm{SCE}}, 3$ )

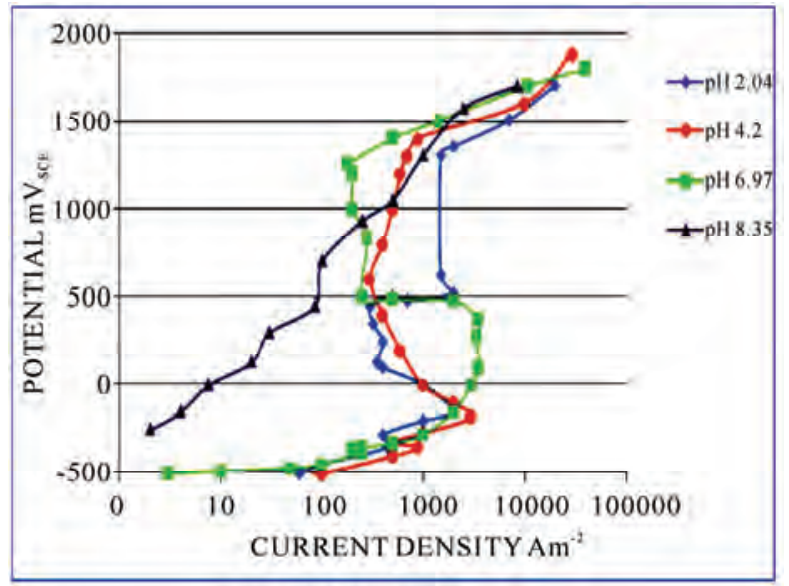

Figure 16. Effect of $\mathbf{p H}$ on the potentiodynamic anodic polarization behavior of mild steel in $52 \mathrm{Wt} \% \mathrm{NH}_{4} \mathrm{NO}_{3}$ solution at $368 \mathrm{~K}$ (sweep rate $0.33 \mathrm{mVs}^{-1}$ ).

Broad active to passive transition peak starting at zero $\mathrm{mV}$ with corresponding current density of 0.85 $\times 10^{3} \mathrm{Am}^{-2}$, 4) Second dissolution regime between + $500 \mathrm{mV}$ and $600 \mathrm{mV}, 5$ ) Second passive plateau at current density of $1.3 \times 10^{3} \mathrm{Am}^{-2}$ between $600 \mathrm{mV}$ and $1300 \mathrm{mV}_{\mathrm{SCE}}$, 6) $\mathrm{A}$ transpassive regime starting at $1300 \mathrm{mV}_{\mathrm{SCE}}$.

- For pH 4.2 1) An active dissolution regime between -500 $\mathrm{mV}_{\mathrm{SCE}}$ and -350 $\mathrm{mV}_{\mathrm{SCE}}$, 2) First active-passive transition starting at $-350 \mathrm{mV}$ with a corresponding current density of $1 \times 10^{3} \mathrm{Am}^{-2}$, 3) An active dissolution regime between $-300 \mathrm{mV}_{\mathrm{SCE}}$ to -150 mV $\mathrm{mCE}_{\mathrm{SC}}$, 4) A second active-passive transition starting at $-150 \mathrm{mV}_{\mathrm{SCE}}$ with a corresponding current density of $3 \times 10^{3} \mathrm{Am}^{-2}$, 5) Transition peak at potential $0 \mathrm{mV}$ with a corresponding current density of $\left.0.6 \times 10^{3} \mathrm{Am}^{-2}, 6\right) \mathrm{A}$ passive plateau at a current density of $0.4 \times 10^{3} \mathrm{Am}^{-2}$ between $500 \mathrm{mV}_{\mathrm{SCE}}$ and $\left.1400 \mathrm{mV}_{\mathrm{SCE}}, 7\right)$ The initiation of the transpassive regime at $1450 \mathrm{mV}_{\mathrm{SCE}}$.

- For pH 6.97 1) An active dissolution regime between $-500 \mathrm{mV}_{\mathrm{SCE}}$ and $-150 \mathrm{mV}_{\mathrm{SCE}}$, 2) A passive plateau at a current density of $3.5 \times 10^{3} \mathrm{Am}^{-2}$ between $-100 \mathrm{mV}_{\mathrm{SCE}}$ and $+500 \mathrm{mV}_{\mathrm{SCE}}$, 3) Sudden decrease in the current density to $0.2 \times 10^{3} \mathrm{Am}^{-2}$ at $-520 \mathrm{mV}_{\mathrm{SCE}}$, 4) passive plateau at current density of $0.2 \mathrm{Am}^{-2}$ between $550 \mathrm{mV}_{\mathrm{SCE}}$ and $1200 \mathrm{mV}_{\mathrm{SCE}}$, 5) The initiation of transpassive regime at $1200 \mathrm{mV}_{\mathrm{SCE}}$.

- For pH 8.35 1) A slow dissolution from -250 mV $\mathrm{mSE}_{\mathrm{SCE}}$ to $800 \mathrm{mV}_{\mathrm{SCE}}$ to a maximum current density of $0.1 \times$ $10^{3} \mathrm{Am}^{-2}$, 2) Another dissolution behavior from 800 $\mathrm{mV}_{\mathrm{SCE}}$ to $1200 \mathrm{mV}_{\mathrm{SCE}}$ to a maximum current density of $0.9 \times 10^{3} \mathrm{Am}^{-2}$, 3) Passive plateau at a current density of $1 \times 10^{3} \mathrm{Am}^{-2}$ between $1200 \mathrm{mV}_{\mathrm{SCE}}$ 
and $1600 \mathrm{mV}_{\text {SCE }}$, 4) The initiation of transpassive regime at $1600 \mathrm{mV}_{\text {SCE }}$.

From above it is clear that the potentiodynamic polarization curves again emphasize the validity of the gravimetric measurement and show the influence of $\mathrm{pH}$ on the anodic dissolution characteristics of mild steel. These results were found to be in accord with previous research [14].

\section{Conclusions}

At very low $\mathrm{pH}$ values, stress corrosion cracking is associated with very high rate of general corrosion. In the region of $\mathrm{pH} 2.0$ to 4.2 the stress corrosion life is relatively unchanged and general corrosion rate decreases with increasing of the $\mathrm{pH}$ level. Between $\mathrm{pH} 4.2$ and 6.0, the corrosion rate and stress corrosion life are almost constant. In the region of $\mathrm{pH} 6.0$ to 7.5 , the stress corrosion life increases slightly and the corrosion rate decreases. Above $\mathrm{pH}$ 7.5, there is a noticeable increase in the stress corrosion life while the general corrosion rate shows a marked decrease. Experimental observation suggests that an oxide film of critical physical properties is formed at immersion. This film suffers localized breakdown at the grain boundary. These limited grain boundary micro fissures will only propagate if aided by stress which facilitates the continuing action of the corrosion process. Subsequently, the precipitation of a layer of stifling corrosion product re-occurs and the cyclic process is repeated until failure. The local dissolution rate at the crack tip is accelerated with test time, which would be attributed to the continuous increase in the stress concentration. This reflects the interaction of stress and anodic dissolution during the SCC process.

\section{REFERENCES}

[1] ASM International, "Metals Handbook (Desk Edition)," Chapter 32 (Failure Analysis), American Society for Metals, 1997.

[2] C. Sean Brossia, et al., "A Study of Stress Corrosion Cracking and Localized Corrosion of Carbon Steel in Nitrate Based Nuclear Waste,” NACE Conference, Georgia, 2009.

[3] R. N. Parkins and R. Usher, "The Effect of Nitrate Solution in Producing Stress Corrosion Cracking in Mild
Steel," Proceeding of the 1st International Congress on Metallic Corrosion, London, 1961, p. 289.

[4] R. N. Parkins, "Environmental Aspect of Stress Corrosion Cracking in Low Strength Ferrite Steels," Proceeding of the International Conference on Stress Corrosion Cracking and Hydrogen Embrittlement of Iron Base Alloys, Firming, 1973.

[5] Y. Z. Wang, R. W. Revie and M. T. Shahatas, "Early Stages of Stress Corrosion Cracks Development of X65 Pipeline Steel in Near Neutral pH Solution,” Materials for Resource Recovery and Transport, L. Collins, Ed., The Metallurgical Society of CIM, Montreal, 1998, p. 71.

[6] R. W. Stachle, "Framework for Predicting Stress Corrosion Cracking," Proceedings of Environmentally Assisted Cracking; Predictive Methods for Risk Assessment and Evaluation of Materials, Equipments and Structure, Orlando, 2000.

[7] K. D. Boomer, J. Beavers, et al., "A Study of Corrosion and Stress Corrosion Cracking of Carbon Steel Nuclear Waste Storage tanks," Material Science and Technology Conference and Exhibition, Michigan, 2007.

[8] F. Gui, C. S. Brossia, et al., "On the Anodic Polarization Behavior of Carbon Steel in Hanford Nuclear Wastes," Corrosion, National Association of Catering Executives, Houston, 2007.

[9] C. S. Brossia, C. Scott, et al., "Inhibition of Stress Corrosion Cracking of Carbon Steel Storage Tanks at Hanford," Corrosion, National Association of Catering Executives, Houston, 2007.

[10] N. Sridhar, et al., "Grain Boundary Chemistry and Weak Link Behavior of Polycrystalline $\mathrm{YBa}_{2} \mathrm{Cu}_{4} \mathrm{O}_{8}$," Proceeding of Environmentally Assisted Cracking Predictive Methods for Risk Assessment and Evaluation of Materials, Equipments and Structure, Vol. 241, Orlando, 2000.

[11] R. G. J. Leferink and W. M. M. Huijbregts, "Nitrate Stress Corrosion Cracking in Waste heat Recovery Boilers," Anti - Corrosion Methods and Materials, Vol. 49, No. 2, 2002, pp. 118-126.

[12] R. N. parkins, et al., "Stress Corrosion Test Method," British Corrosion Journal, Vol. 7, 1972, p. 154.

[13] F. S. Mohammed, "Stages of Corrosion Cracking of Mild Steel in Nitrate Solution," 3rd International Material Conference, College of Engineering, Australia, 2008.

[14] Corrosion Source, Last Revised December 2005. http:// www.corrosionsource.com/handbook/testing/scc.htm 